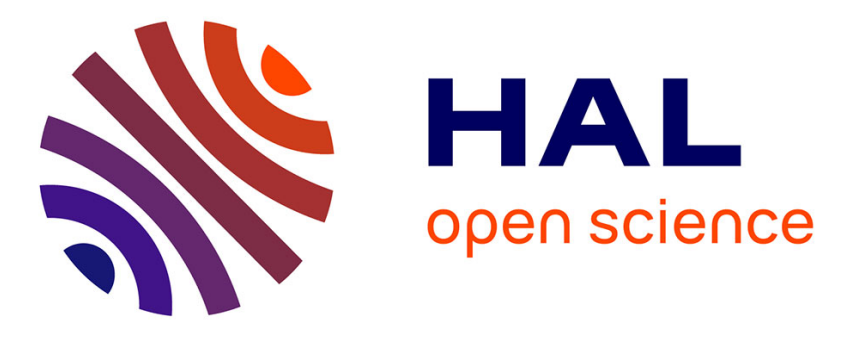

\title{
Aluminum oxide nanowires as safe and effective adjuvants for next-generation vaccines
}

Rostyslav Bilyy, Solomiya Paryzhak, Kostiantyn Turcheniuk, Tetiana

Dumych, Alexandre Barras, Rabah Boukherroub, Fujia Wang, Gleb Yushin, Sabine Szunerits

\section{To cite this version:}

Rostyslav Bilyy, Solomiya Paryzhak, Kostiantyn Turcheniuk, Tetiana Dumych, Alexandre Barras, et al.. Aluminum oxide nanowires as safe and effective adjuvants for next-generation vaccines. Materials Today, 2019, 22 (58-66), 10.1016/j.mattod.2018.10.034 . hal-01944313

\section{HAL Id: hal-01944313 \\ https://hal.science/hal-01944313}

Submitted on 17 Dec 2018

HAL is a multi-disciplinary open access archive for the deposit and dissemination of scientific research documents, whether they are published or not. The documents may come from teaching and research institutions in France or abroad, or from public or private research centers.
L'archive ouverte pluridisciplinaire HAL, est destinée au dépôt et à la diffusion de documents scientifiques de niveau recherche, publiés ou non, émanant des établissements d'enseignement et de recherche français ou étrangers, des laboratoires publics ou privés. 


\section{Aluminum oxide nanowires as safe and effective adjuvants for next-generation vaccines}

Rostyslav Bilyy ${ }^{1}{ }^{1}$, Solomiya Paryzhak ${ }^{1}$, Kostiantyn Turcheniuk ${ }^{2}$, Tetiana Dumych ${ }^{1}$, Alexandre Barras ${ }^{3}$, Rabah Boukherroub ${ }^{3}$, Fujia Wang ${ }^{2}$, Gleb Yushin ${ }^{2}$, Sabine Szunerits ${ }^{3, *}$

\footnotetext{
${ }^{1}$ Danylo Halytsky Lviv National Medical University, 79010 Lviv, Ukraine

${ }^{2}$ Georgia Institute of Technology, School of Materials Science and Engineering, Atlanta, GA 30332, USA

${ }^{3}$ Univ. Lille, CNRS, Centrale Lille, ISEN, Univ. Valenciennes, UMR 8520 - IEMN, F-59000 Lille, France
}

Improving efficiency of an adjuvant, material that enhances the body's immune response to an antigen, has become vital for the development of safer, cheaper, and more effective next-generation vaccines. Commercial vaccines typically use aluminum salt-based adjuvant particles, most commonly aluminum oxyhydroxide $(\mathrm{AlOOH})$ and aluminum hydroxide $\left(\mathrm{Al}(\mathrm{OH})_{3}\right)$ based often referred to as "alum". Despite their broad use, their adjuvant properties are rather moderate. This is even worse in the case of aluminum oxide $\left(\mathrm{Al}_{2} \mathrm{O}_{3}\right)$-based adjuvant. While being more robust and less cytotoxic, $\mathrm{Al}_{2} \mathrm{O}_{3}$ is a significantly less effective adjuvant than above-mentioned $\mathrm{Al}$ compounds and is consequently not commonly used. Here, we report on the remarkably enhanced adjuvant properties of $\mathrm{Al}_{2} \mathrm{O}_{3}$ when produced in the form of nanowires (NWs). Based on recent advances in understanding neutrophil activation by inert nanoscaffolds, we have created ultra-long $\mathrm{Al}_{2} \mathrm{O}_{3} \mathrm{NWs}$ with a high aspect ratio of $\sim 1000$. These NWs showed strong humoral immune response with no damaging effect on the microvasculature. Since only the change of shape of Al adjuvants is responsible for the excellent adjuvant properties, our finding holds great promise for rapid implementation as safer and more effective adjuvant alternative for human vaccines. The mechanism behind human blood-derived neutrophil activation with $\mathrm{Al}_{2} \mathrm{O}_{3} \mathrm{NWs}$ was found to be sequestering of $\mathrm{Al}_{2} \mathrm{O}_{3} \mathrm{NWs}$ by neutrophils via formation of neutrophil extracellular traps (NETs).

\section{Introduction}

Vaccination has made an enormous contribution to global health and is considered one of the greatest medical accomplishments for achieving global safety against dangerous diseases. Since the efficiency of a particular vaccine correlates directly with the percentage of a given population that has been vaccinated, the vaccine market requires cost-effective and efficient solutions to attain broad vaccination coverage [1]. The technologies

\footnotetext{
* Corresponding authors.

E-mail addresses: Bilyy, R. (r.bilyy@gmail.com), Yushin, G. (gleb.yushin@mse.gatech.edu), Szunerits, S. (sabine.szunerits@univ-lille1.fr).
}

involved in manufacturing different types of vaccines influence strongly vaccine costs. The high price of antigen expression makes many vaccines less affordable to (and thus less used by) low-income population [2]. Adding effective adjuvants to vaccine formulation enhances vaccines in two possible ways: (a) it allows the use of smaller antigen doses or physically small adjuvant molecules (meaning synthetic pathogenic components instead of attenuated risky pathogens) and (b) it leads to enhanced antibody titers, decreasing the number or revaccinations and maintaining the reliable antibody levels during whole life [3]. Furthermore, improving the efficiency of adju- 
vants to enhance the body's immune response to an antigen would allow the development of next generation of safer, more effective, and more affordable vaccines.

Aluminum (Al) salt-based adjuvants (most commonly in the form of aluminum oxyhydroxide $(\mathrm{AlOOH})$, aluminum hydroxide $\left(\mathrm{Al}(\mathrm{OH})_{3}\right)$ are used in human vaccines since 1930s and are commonly referred to as "alum" [4-6]. The presence of oxygencontaining groups on their surface [7-9] provides fast antigen adsorption and yield a vigorous response from the immune system compared to alternatives [10]. While aluminum oxide $\left(\mathrm{Al}_{2} \mathrm{O}_{3}\right)$ is more robust, it is significantly less effective than other Al-based adjuvants and is commonly much less used. Furthermore, Al salt-based adjuvants exhibit relatively low cytotoxicity as compared to pathogen stimulants or virusomes and have proven to cause a fewer number of local severities $[11,12]$.

Recent studies showed that the shape and dimensions of the adjuvant particles may affect the immune response against protein and peptide antigens $[13,14]$. For example, enhanced adjuvant activity of small, elongated particles (nanorods or nanosticks) of $\mathrm{AlOOH}$ and $\mathrm{Al}(\mathrm{OH})_{3}$ with diameters of $4-20 \mathrm{~nm}$ and aspect ratio of 8-10 was recently reported [14-16], although the origin of the improved performance remained largely unclear.

Earlier, some of us demonstrated that different size nanoparticles thrust the activity of neutrophils, which boosts the immune system response toward co-injected antigens $[17,18]$. This mechanism of neutrophils activation is highly dependent on the size of the particles, e.g. bacteria, fungi, nano- and microparticles $[18,19]$. It results in the formation of neutrophil extracellular traps (NETs), which effectively isolate foreign bodies and suppress local self-limiting inflammation [20]. The mechanism of NETs' action is realized by the entrapping of foreign particles by unbound DNA and histones, both decorated by toxic proteinous content of neutrophils' granules [21]. Formation of NETs was recently demonstrated as an important player responsible for adjuvant action of injected alum, reported to recruit neutrophils, and their activation leading to stimulation of DNA sensors and provoking local inflammatory response [22].

Since the NETs' formation is particles' size-dependent, we hypothesized that the utilization of high-aspect ratio Al-based vaccine adjuvants can greatly contribute to establishing more potent immune responses through neutrophils' activation. Unfortunately, relatively expensive synthesis of nanorods (due to the use of harsh chemicals, elevated reaction temperatures, and low reaction yields), which was demonstrated earlier [14], as well as their potential damages to the smallest blood vessels may become barriers for their use in low-cost vaccination.

In this article, we have chosen to investigate if $\mathrm{Al}_{2} \mathrm{O}_{3}$ nanowires (NWs) can activate neutrophil cells upon injection to the body and possibly enhance adjuvant properties over other Albased adjuvants. We choose to compare our findings to aluminum-based adjuvants, commonly used in commercially available vaccine formulations. Our interest was partially triggered by our recent discovery of an innovative approach for ultra-low-cost synthesis of $\gamma$-alumina NWs $\left(\gamma-\mathrm{Al}_{2} \mathrm{O}_{3} \mathrm{NWs}\right)$ of variable dimensions and controllable aspect ratio [23,24]. These nanomaterials are produced by exposing bulk $\mathrm{Al}$ alloys to alcohols at near room temperature and atmospheric pressure, fol- lowed by heat treatment in air. No catalysts, toxic metals, external stimuli, or costly synthesis systems are required. We expect the future industrialization will allow formation of these $\gamma-\mathrm{Al}_{2} \mathrm{O}_{3} \mathrm{NWs}$ at a cost of a few dollars per pound, which is almost negligible for vaccination applications. The tests conducted for the first time on 20 - to 60 -micron-long, $20-40 \mathrm{~nm}$ diameter, $\sim 1000$ aspect ratio NWs substantially exceeded our expectations and demonstrated $\gamma-\mathrm{Al}_{2} \mathrm{O}_{3} \mathrm{NWs}$ to be extremely effective vaccine adjuvant, inducing excellent humoral immune response. Quite remarkably, $\gamma-\mathrm{Al}_{2} \mathrm{O}_{3} \mathrm{NWs}$ did not damage the microvasculature of the tissues and were found to be easily entrapped by NETs and passivated. When compared with state of the art commercial Al-based adjuvant, the proposed low-cost $\gamma-\mathrm{Al}_{2} \mathrm{O}_{3}$ NWs were found to be both more efficient and safer. Our findings highlight great promises of NWs for substantial breakthroughs in the development of safer, more effective, and more affordable vaccines.

\section{Results and discussion}

$\gamma-\mathrm{Al}_{2} \mathrm{O}_{3} \mathrm{NWs}$ have been synthesized by the protocol described by some of us previously [23]. It relies on the de-alloying of bulk AlLi alloy in ethanol at $60^{\circ} \mathrm{C}$ for $24 \mathrm{~h}$, which yields $\mathrm{Al}$ ethoxide NWs. Subsequent heat-treatment at $800^{\circ} \mathrm{C}$ for $1 \mathrm{~h}$ results in the formation of $\gamma-\mathrm{Al}_{2} \mathrm{O}_{3} \mathrm{NWs}$, as shown in the scanning electron microscopy (SEM) micrograph (Fig. 1a). The microstructure of the NWs is uniform. The average NWs' thickness is $\sim 20 \mathrm{~nm}$, average length $20-60 \mu \mathrm{m}$, and aspect ratio exceeding $\sim 1000$. We believe that the dimensions of the NWs are sufficient to activate neutrophils (typically $12-17 \mu \mathrm{m}$ in diameter). In particular, of a typical length of $35 \mu \mathrm{m}$ [25], the crystals of monosodium urate, which are formed in the condition of the gout, can be effectively ingested by the neutrophils $[26,27]$. The crystallinity of the $\gamma-\mathrm{Al}_{2} \mathrm{O}_{3}$ NWs was revealed by the transmission electron microscopy micrograph (TEM, Fig. 1b). The $\gamma-\mathrm{Al}_{2} \mathrm{O}_{3}$ NWs are polycrystalline with an average crystal diameter of 15-20 nm. The rough surface and sharp ends of the $\gamma-\mathrm{Al}_{2} \mathrm{O}_{3}$ NWs can promote the membrane damage in neutrophils, resulting in the promotion of the NET formation [18]. The characteristic selected area electron diffraction (SAED) pattern in Fig. $1 \mathrm{~b}$ area exhibits strong and prominent diffraction rings indexed as 311, 222, 400 , and 440 reflections of $\gamma-\mathrm{Al}_{2} \mathrm{O}_{3}$ (Fig. 1c). Thermogravimetric analysis (TGA) shows clearly the conversion of $\mathrm{Al}(\mathrm{OEt})_{3} \mathrm{NWs}$ to $\mathrm{Al}_{2} \mathrm{O}_{3}$ NWs (Fig. 1c). Organic carbon- and hydrogen-containing groups, which constitute almost $\sim 40 \mathrm{wt} . \%$ of the mass, burn in air until $400^{\circ} \mathrm{C}$. In the range of $500-1000^{\circ} \mathrm{C}$, the mass of the $\mathrm{Al}_{2} \mathrm{O}_{3} \mathrm{NWs}$ is stabilized. The high-angle XRD pattern (Fig. 1d) of the $\mathrm{Al}_{2} \mathrm{O}_{3} \mathrm{NWs}$ displays diffraction peaks at $2 \theta$ of $14.66^{\circ}$, $37.18^{\circ}, 39.03^{\circ}, 45.36^{\circ}, 60.15^{\circ}$, and $66.70^{\circ}$, indexed as (2 20$)$, (3 11 ), (2 22$),(400),(511)$, and (4 40$)$ crystal planes of $\gamma$ $\mathrm{Al}_{2} \mathrm{O}_{3}$ NWs, respectively. The chemical composition of $\gamma-\mathrm{Al}_{2} \mathrm{O}_{3}$ NWs was further validated by FTIR (Fig. 1e) and XPS analysis (Fig. 1f). The FTIR spectrum exhibits a broad band centered at $3495 \mathrm{~cm}^{-1}$ due to $\mathrm{OH}$ (stretching) band and/or adsorbed water. There is a general lack of peaks related to oxygen-containing groups besides the presence of bands related to $\mathrm{AlOOH}$, such as the bands at 3298, 3091, 1070, and 1165, assigned to $v_{\mathrm{as}}(\mathrm{Al})$ $\mathrm{OH}, v_{\mathrm{s}}(\mathrm{Al})-\mathrm{OH}$, stretching vibrations, and $\delta_{\text {as }} \mathrm{Al}-\mathrm{O}-\mathrm{H}$ modes for 

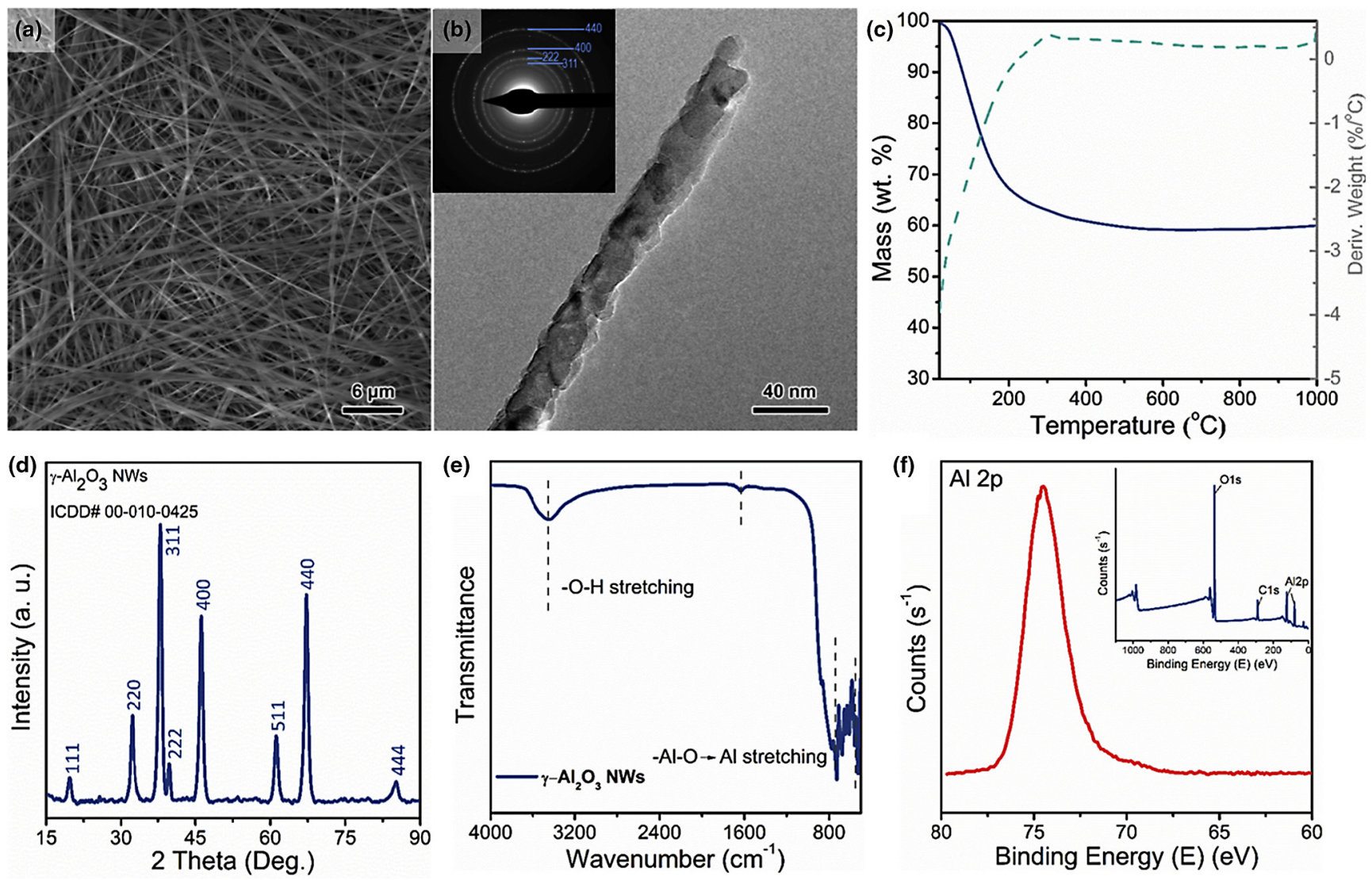

FIG. 1

Characterization of $\gamma-\mathrm{Al}_{2} \mathrm{O}_{3}$ nanowires: (a) SEM micrograph; (b) TEM micrograph and SAED; (c) TGA; (d) XRD pattern; (e) FTIR; (f) XPS survey (inset) and characteristic of the $\mathrm{Al}_{2 p}$ core level.

AlOOH. The bands below $1000 \mathrm{~cm}^{-1}$ at 864,749 , and $583 \mathrm{~cm}^{-1}$ are caused by the formation of the $\gamma-\mathrm{Al}_{2} \mathrm{O}_{3}$ phase. Furthermore, the XPS survey spectrum, together with the high-resolution core-level spectrum of $\mathrm{Al}_{2 \mathrm{p}}(74.6 \mathrm{eV})$, is shown in Fig. $1 \mathrm{f}, \mathrm{g}$ (inset). The atomic ratio between $\mathrm{Al}_{2 \mathrm{p}} / \mathrm{O}_{1 \mathrm{~s}}$ is 0.65 close to that of the theoretical value of 0.66 for $\gamma-\mathrm{Al}_{2} \mathrm{O}_{3}$.

A commercial Al-based adjuvant (alum) (Fig. S1a) and commercial aluminum oxide microparticles ( $\left.\mathrm{Al}_{2} \mathrm{O}_{3} \mathrm{MPs}\right)$ (Fig. S1b) were used as control materials throughout this study. Fig. S1c shows X-ray diffraction (XRD) patterns of alum. The XRD patterns indicate that alum has an aluminum oxide hydroxide $(\gamma$ $\mathrm{AlO}(\mathrm{OH})$ ) (boehmite) structure with the average crystallite size $2.2 \mathrm{~nm}$ (Fig. S1). Zeta-potential measurements in water at $25^{\circ} \mathrm{C}$ (Fig. S1d) indicate that alum adjuvant formulation has a positive surface charge of $+6.6 \pm 0.3 \mathrm{mV}$ (Table S1). This is only slightly higher than that of the $\gamma-\mathrm{Al}_{2} \mathrm{O}_{3} \mathrm{NWs}$ with a surface charge of $+2.2 \pm 1.5 \mathrm{mV}$. Surprisingly, using $\mathrm{Al}_{2} \mathrm{O}_{3} \mathrm{MPs}$, a negative surface charge was recorded. The positive surface charge of $\gamma-\mathrm{Al}_{2} \mathrm{O}_{3} \mathrm{NWs}$ may be advantageous to facilitate the electrostatic binding of negatively charged proteins. Indeed, incubation of $\gamma-\mathrm{Al}_{2} \mathrm{O}_{3}$ NWs in water supplemented with $0.2 \%$ ovalbumin (OVA) results in a material with negative (about $-25.6 \mathrm{mV}$ ) surface charge due to the adsorption of OVA. The same was true for the alum adjuvant.

The cell toxicity of $\gamma-\mathrm{Al}_{2} \mathrm{O}_{3}$ NWs was tested on HeLa and U87MG cell lines after 24-h incubation (Fig. S2a-b). In addition, and in the belief that $\gamma-\mathrm{Al}_{2} \mathrm{O}_{3}$ NWs will be mainly processed by macrophages, cytotoxicity studies of this cell type were included (Fig. S2c).

The cytotoxicity of the different materials was evaluated based on cell viability assessment by MTS assay relative to controls as proposed by Kong et al. [28]: non-toxic $>90 \%$ cell viability, slightly toxic $65-90 \%$, toxic $35-65 \%$, severe toxic $<35 \%$. All the nanostructures appeared nontoxic for HeLa cells after $24 \mathrm{~h}$ of exposure even at high concentrations. This was also true for $\mathrm{Al}_{2} \mathrm{O}_{3}$ MPs alone. Using U87MG human brain cells, in the case of $\gamma-\mathrm{Al}_{2} \mathrm{O}_{3} \mathrm{NWs}$ at concentrations $>100 \mu \mathrm{g} \mathrm{mL}^{-1}$, the nanostructures proved to be slightly toxic after $24 \mathrm{~h}$ of exposure. The same was observed for alum. Interestingly, $\mathrm{Al}_{2} \mathrm{O}_{3} \mathrm{MPs}$ had a different cytotoxic behavior on these cell lines: at concentrations between 200 and $400 \mu \mathrm{g} \mathrm{mL}^{-1}$, the structures were slightly toxic and reached toxic levels for concentrations $\geq 500 \mu \mathrm{g} \mathrm{mL}^{-1}$.

In order to test adjuvant properties of $\gamma-\mathrm{Al}_{2} \mathrm{O}_{3} \mathrm{NWs}$, we have determined both parts of immune responses, namely humoral and cellular immune responses. Immunization experiments were performed on Balc/c laboratory mice using chicken egg OVA as model antigen. The presence of anti-ovalbumin antibodies, both IgG and IgM types, was measured before immunization (day 0), as well as after 14 and 35 days of immunization (Fig. 2a,b, Fig. S3, Fig S4a-b). The humoral immune response after a second vaccination caused by the " $\gamma-\mathrm{Al}_{2} \mathrm{O}_{3}$ NWs + OVA" was significantly stronger compared to that effect of "alum + OVA" 
(a)

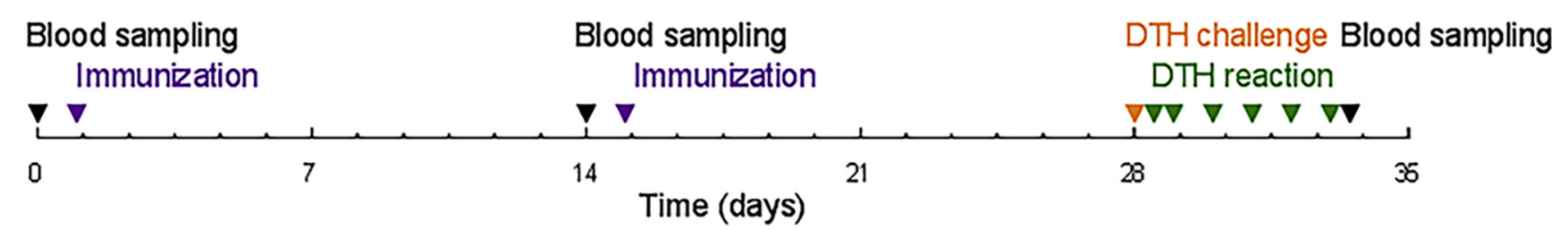

(b)

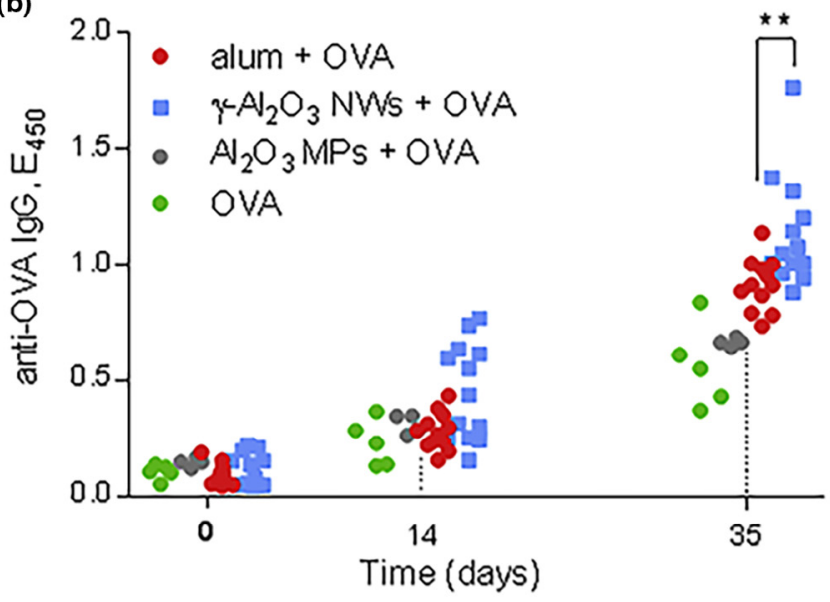

(c)

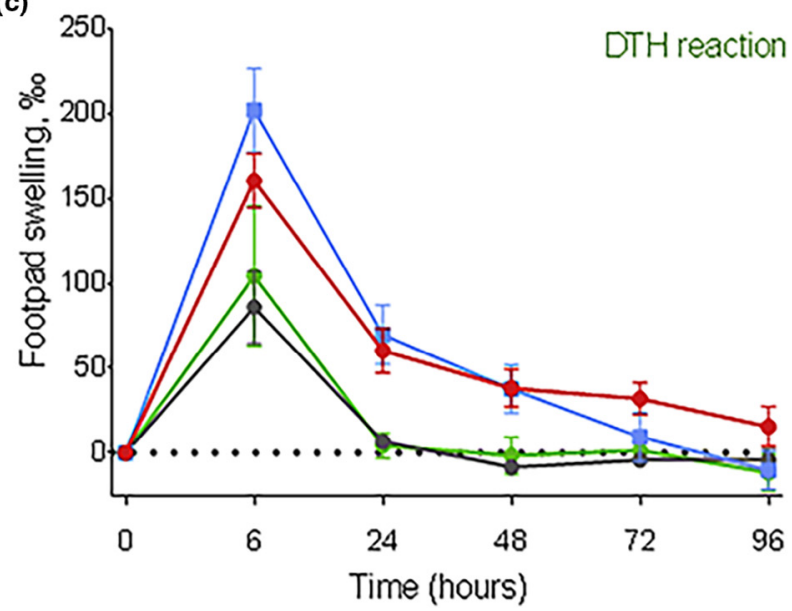

FIG. 2

Humoral and cellular immune responses in Balb/c mice provoked by OVA using alum, $\gamma \gamma-\mathrm{Al}_{2} \mathrm{O}_{3} \mathrm{NWs}, \mathrm{Al}_{2} \mathrm{O}_{3} \mathrm{MPs}$, or OVA alone acting as adjuvants: (a) experimental design and (b) humoral immune response. Anti-OVA IgG-specific levels in serum (humoral immune response), each dot represent the response of specific animal; sera dilution was 1:2000; (c) cellular immune response; DTH reaction measured as a foot swelling. Data are $\mathrm{M} \pm$ sem for all studied animals in the group; $n=12,13,4,5$, correspondingly.

(Fig. 2b), as indicated by the significantly higher amount of antiOVA IgG antibodies formed 35 days after immunization at the dilution factor of $1 / 2000$. Further analysis of antibody titers (dilution factor at which antibody is still effective) revealed (Fig. S3) that titers of antibodies obtained after $\gamma-\mathrm{Al}_{2} \mathrm{O}_{3} \mathrm{NWs}$ + OVA immunization were 1/64000; after the use of alum $1 / 16000$, for $\mathrm{Al}_{2} \mathrm{O}_{3}$ MPs and OVA alone, they were as low as $1 / 2000$ and $1 / 1000$, correspondingly; the cut-off was set to 0.5 OD value (Fig. S3). Both adjuvants were not inducing acutephase antibodies of IgM type (Fig S4b), which signifies that there is no inflammation left.

The cellular immune response was assessed using an established model of delayed type hypersensitivity (DTH) reaction [29], modified by us to be less invasive animal treatment protocol [18]. The DTH is a part of the cell-mediated immune response associated with Th1 reactivity in response to insoluble foreign antigens. It is a localized inflammatory reaction prototypical in vivo assay to study cell-mediated host immune response mediated by CD4+ T lymphocytes (small leukocytes, white blood cells). These cells promote T-helper cell type 1 (Th1) production of interferon- $\gamma$ (a soluble cytokine). This immune response is characterized by an influx of innate immune cells, with macrophages and the dendritic cells predominating. Therefore, after the formation of antibodies (day 28), mice were challenged with OVA injected between the fingers of the footpad (right foot), while PBS served as control and injected to the left foot (Fig. 2a). Footpad swelling, being proportional to the strengths of cellular immune response, was measured in dynamics for few days, until swelling disappeared. The DTH reaction (usually evaluated at 6-24 h after antigen exposure) was comparable for both groups of animals, immunized with OVA in the presence of either alum or $\gamma-\mathrm{Al}_{2} \mathrm{O}_{3} \mathrm{NWs}$ (Fig. 2c), while it was significantly lower for $\mathrm{Al}_{2} \mathrm{O}_{3} \mathrm{MPs}$ or OVA alone. The swelling of the footpad faded after $72 \mathrm{~h}$ of the DTH challenge, which correlates with the normal responsiveness to the antigen. Absence of exaggerated cellular response with much stronger humoral response for $\gamma-\mathrm{Al}_{2} \mathrm{O}_{3}$ NWs makes them immunologically favorable agents for the use in vaccines.

Some of us have recently shown that nanoscaffolds may be able to induce activation of polymorphonuclear neutrophils to form neutrophil extracellular traps [18], networks of extracellular fibers produced as an immune response to neutralize infection [30]. Localization of neutrophils leads to localized self-limiting inflammation, which results in isolation of inflammatory stimuli with NETs [31] and, as discovered recently, is an important trigger of alum action [22]. This phenomenon is mainly responsible for the strong self-limiting (fast resolved) inflammation caused by some nanoparticles [18] (best illustrated by gout attack, caused by monosodium urate needle-like crystals, to be as spontaneously resolved as it appears).

Since $\gamma-\mathrm{Al}_{2} \mathrm{O}_{3}$ NWs provoked increased humoral immune response, we were interested to follow up the fate of the $\gamma$ $\mathrm{Al}_{2} \mathrm{O}_{3} \mathrm{NWs}$ upon injection in the body. We used a lately described mouse air pouch model [32], where sterile air is injected under the skin at the back of the mouse to form a cavity, which is being infiltrated with immune cells followed by $\gamma-\mathrm{Al}_{2} \mathrm{O}_{3}$ 


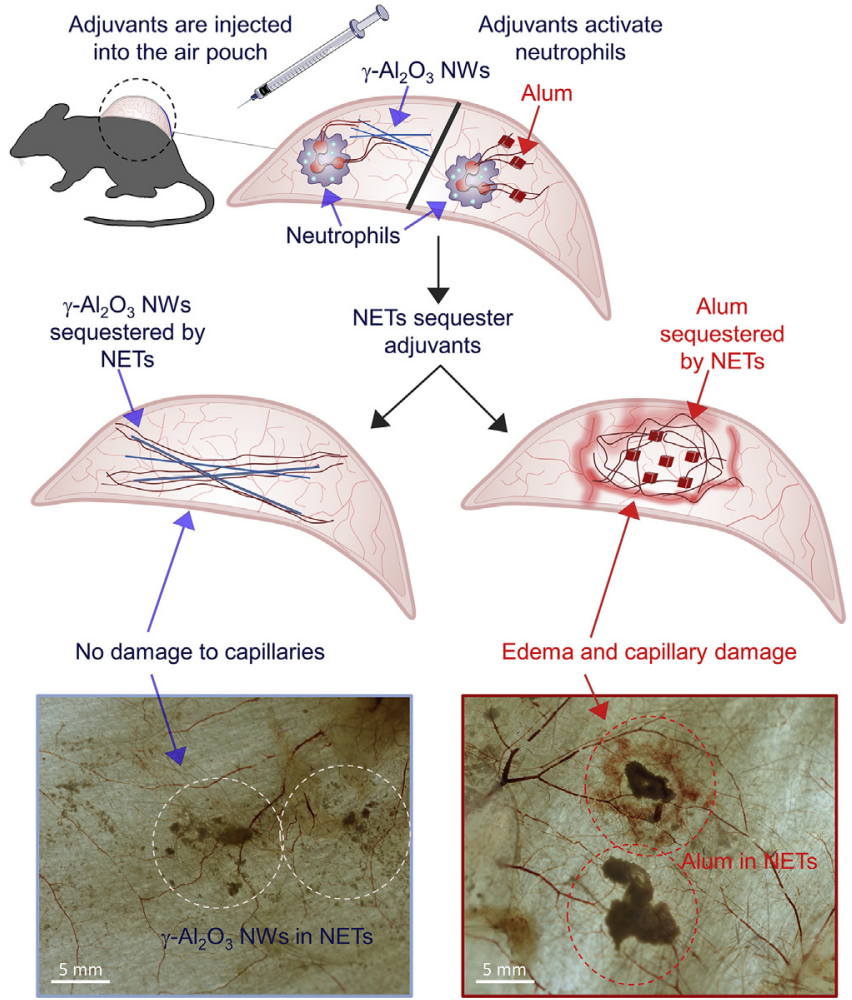

FIG. 3

Formation of neutrophil extracellular traps (NETs): sequestering of $\gamma-\mathrm{Al}_{2} \mathrm{O}_{3}$ NWs and alum by aggregated NETs after $24 \mathrm{~h}$ of incubation in mouse air pouch. Dotted red circles show capillary damage and edema. No significant damage to capillaries is observed after $\gamma-\mathrm{Al}_{2} \mathrm{O}_{3} \mathrm{NWs}$ ' treatment.

NWs' injection ( $1 \mathrm{mg} \gamma-\mathrm{Al}_{2} \mathrm{O}_{3} \mathrm{NWs}$ per mouse). Within $24 \mathrm{~h}$ after $\mathrm{NWs}^{\prime}$ injection, mice were sacrificed, and their skin was observed for aggregated NETs and visual damage by microphotography. For both $\gamma-\mathrm{Al}_{2} \mathrm{O}_{3}$ NWs and alum, we have observed abundant formation of aggregated NETs entrapping injected $\mathrm{Al}$ compounds (Fig. 3., S5). However, micro-capillary damage and edema were significantly less visible for $\gamma-\mathrm{Al}_{2} \mathrm{O}_{3} \mathrm{NWs}$ than for commercial alum. It is known that swelling and edema often arise at the place of vaccine injection, which is accompanied by the release of histamines [33]. However, the exact molecular mechanism of how injection of alum results in edema remains unknown $[22,34]$. Therefore, the remarkable properties of $\gamma-\mathrm{Al}_{2} \mathrm{O}_{3} \mathrm{NWs}$ of not causing edema are highly beneficial for potential applications as adjuvants. Their utilization will result in less swelling, edema, and irritation at the place of injection.

To elucidate the mechanism of the $\gamma-\mathrm{Al}_{2} \mathrm{O}_{3} \mathrm{NWs}$ adjuvant properties and related neutrophil activation, we tested their ability to stimulate NETs' formation in human blood-derived neutrophils. For this reason, we obtained a venous blood from 3 healthy volunteers and isolated neutrophil population in sterile conditions. Then neutrophils were placed in multi-well plate containing Sytox Green, a fluorescent dye, which senses extracellular DNA (those externalized from neutrophils in the case of NETs' formation). Positive strong (phorbol myristyl acetate, PMA) and weak (48 mM bicarbonate) inducers of NETs' formation were applied to cell well, simultaneously with $\gamma-\mathrm{Al}_{2} \mathrm{O}_{3}$ NWs, alum, or $\mathrm{Al}_{2} \mathrm{O}_{3}$ MPs. Fig. 4 shows the data of neutrophil activation, isolated from 3 different healthy donors. From the mean fluorescence intensity (MFI) level, it is evident that $\gamma$ $\mathrm{Al}_{2} \mathrm{O}_{3}$ NWs exhibit immediate to strong NET formation upon the contact with the isolated neutrophils. The same was true for alum, the structure of which can also be regarded as 1D material (please see elongated shapes of the fibers in Fig. S1A). In contrast, the $\mathrm{Al}_{2} \mathrm{O}_{3}$ MPs did not induce such an effect. This is an important finding, which confirms that the improved humoral response of $\gamma-\mathrm{Al}_{2} \mathrm{O}_{3} \mathrm{NWs}$ is most likely to be linked to their outstanding structural characteristics. Based on our previous findings, we suspect that a combination of high aspect ratio and small diameter of $\gamma-\mathrm{Al}_{2} \mathrm{O}_{3}$ NWs effectively activates neutrophils by causing local disturbances in lipid bilayer composition followed by membrane re-cycling. The same level of neutrophils' activation, although seen for alum, does result in the membrane damaging and lower levels of humoral immune response as compared to the $\gamma-\mathrm{Al}_{2} \mathrm{O}_{3}$ NWs. It also corroborates our hypothesis that not only the chemical composition, but also the shape and size of the adjuvant may have a profound effect on activation and interaction with NETs.

Based on obtained data, we propose the mechanism of enhanced action of $\gamma-\mathrm{Al}_{2} \mathrm{O}_{3}$ NWs as an adjuvant. $\gamma-\mathrm{Al}_{2} \mathrm{O}_{3} \mathrm{NWs}$ adsorb antigens and upon injection release them; this results in local macrophage and neutrophil activation (Fig. 5a). Macrophages process the antigens and stimulate antibody production through plasma cells (Fig. 5b). Additionally, at the early time upon neutrophil contact with $\gamma-\mathrm{Al}_{2} \mathrm{O}_{3} \mathrm{NWs}$, the former release NETs and cytokines, and significantly enhance antibody production (Fig. 5b). Within $24 \mathrm{~h}, \gamma-\mathrm{Al}_{2} \mathrm{O}_{3} \mathrm{NWs}$ are sequestered by NETs, which limits the inflammation caused by the presence of the foreign $\gamma-\mathrm{Al}_{2} \mathrm{O}_{3} \mathrm{NWs}$ ' particles (Fig. 5c). The $\gamma-\mathrm{Al}_{2} \mathrm{O}_{3} \mathrm{NWs}$ reside locally within the traps without damaging the microvasculature or causing local inflammation. Sufficient concentration of antibodies is achieved in the body as the result of the " $\gamma-\mathrm{Al}_{2} \mathrm{O}_{3}$ NWs' adjuvant + antigen" vaccination.

\section{Conclusions}

This study demonstrates for the first time the extremely promising performance of long (20-60 microns) small diameter (20$40 \mathrm{~nm})$, high aspect ratio $(>1000) \gamma-\mathrm{Al}_{2} \mathrm{O}_{3}$ nanowires (NWs) as a material that enhances the body's immune response to an antigen. The results are particularly encouraging because $\mathrm{Al}_{2} \mathrm{O}_{3}$ is commonly considered to be rather ineffective as an adjuvant. Compared to conventional $\mathrm{Al}_{2} \mathrm{O}_{3}$ microparticles, $\gamma-\mathrm{Al}_{2} \mathrm{O}_{3} \mathrm{NWs}$ exhibited noticeably reduced cell toxicity and dramatically stronger neutrophil activation. Furthermore, $\gamma-\mathrm{Al}_{2} \mathrm{O}_{3} \mathrm{NWs}$ showed improved humoral immune responses, resulting in 4-fold $(1 / 64000$ vs $1 / 16000)$ higher antibody titers and significantly less damages to microvasculature when compared to alum, a commonly chosen vaccine adjuvant. Our study further revealed that $\gamma-\mathrm{Al}_{2} \mathrm{O}_{3} \mathrm{NWs}$ can effectively activate polymorphonuclear neutrophils to form neutrophil extracellular traps (NETs), thereby explaining their outstanding properties. The following neutralization of the NWs in the aggregated NETs explains the selflimiting nature of the NWs' inflammatory effect, which makes NWs safer candidates for common vaccines. We expect the ultra-low cost of the NWs' synthesis in combination with their 
(a)

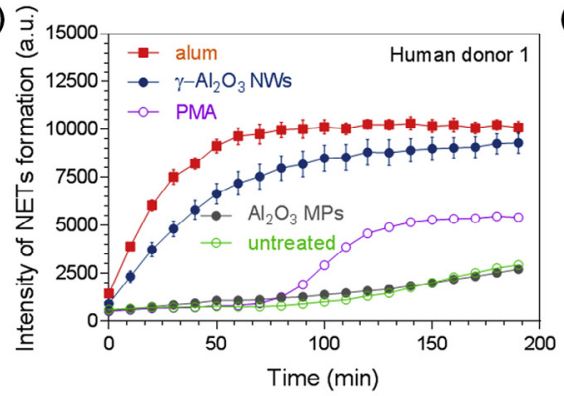

(d)

Neutrophils activation -

NETs formation

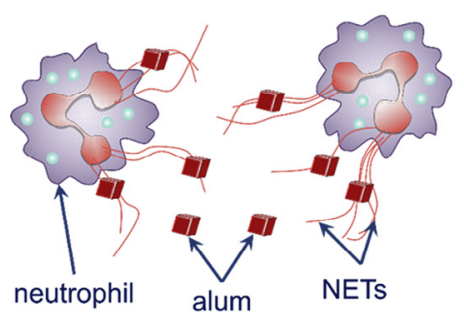

(b)

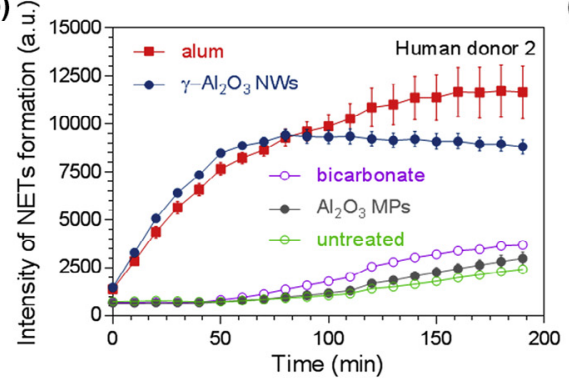

(e) Neutrophils activation -

NETs formation

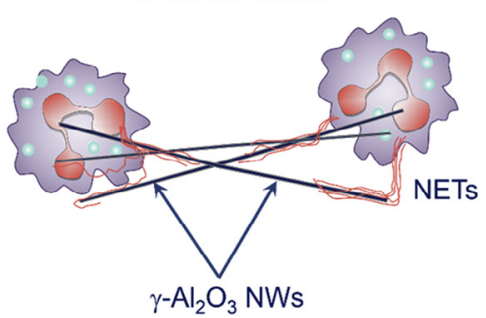

(c)

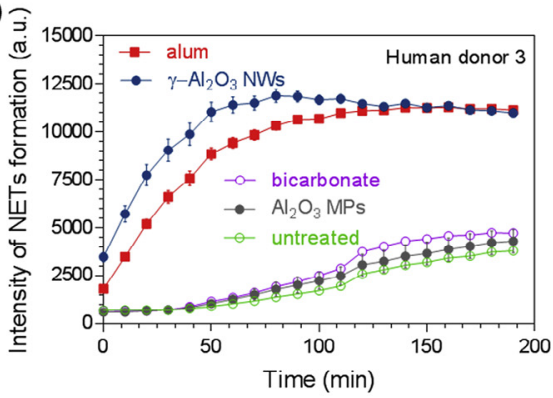

(f) No activation of neutrophils

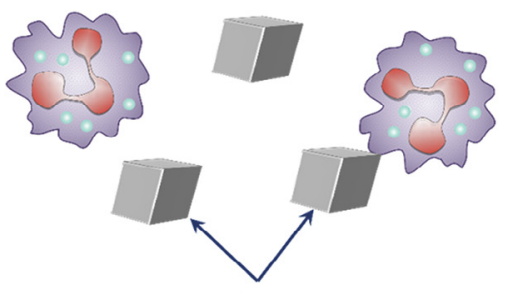

FIG. 4

Activation of peripheral blood-derived neutrophils upon the contact of Al-based adjuvants. Data of three different healthy donors (a-c) are presented. Intensity of NETs' formation is presented as a mean fluorescent intensity of Sytox green dye upon the contact with extracellular DNA: $\gamma-\mathrm{Al}_{2} \mathrm{O}_{3} \mathrm{NWs}$ and alum but not $\mathrm{Al}_{2} \mathrm{O}_{3}$ MPs cause rapid activation of human peripheral blood neutrophils ( $d-f$ ), which is noticeable during the first minutes of incubation. Strong (PMA) and weak (48 $\mathrm{mM}$ bicarbonate) inducers of NETs' formation show their response after $120 \mathrm{~min}$.

(a)

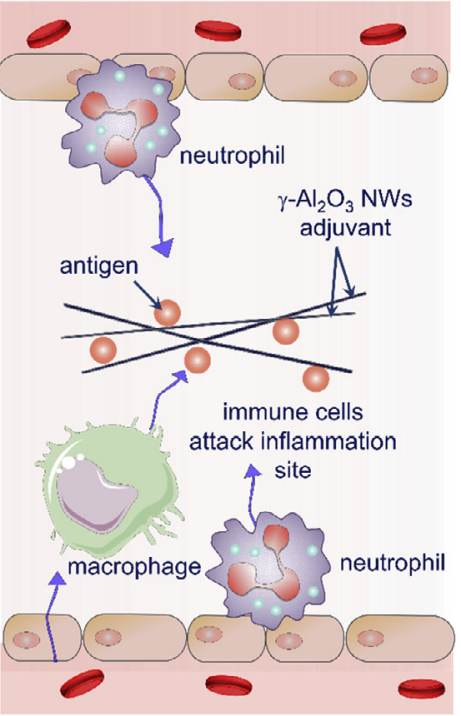

(b)
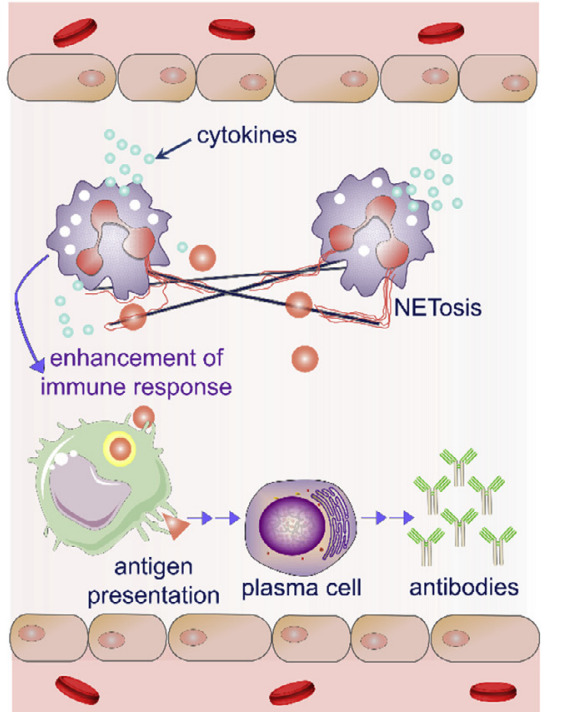

(c)

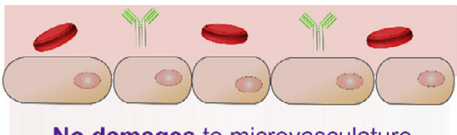

No damages to microvasculature sequestering \& neutralization of $\mathrm{Al}_{2} \mathrm{O}_{3} \mathrm{NWs}$

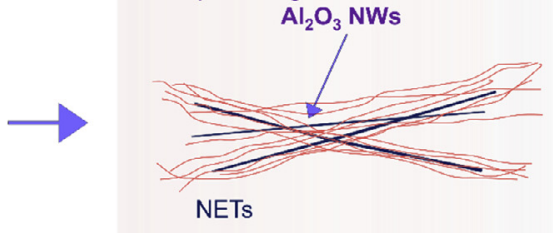

circulation of antibodies into blood

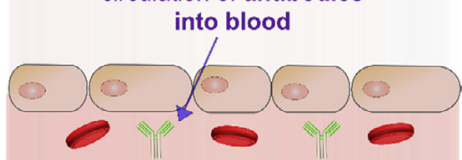

FIG. 5

Brief schematics of the process of the immunization by the $\gamma-\mathrm{Al}_{2} \mathrm{O}_{3}$ NWs-OVA (see text for description).

extremely promising performance may open the door to new families of next-generation adjuvants for better, safer, and cheaper human vaccines. We also expect that modifying NWs' surface chemistry and optimizing their dimensions and morphology may boost their performance further.

\section{Materials and methods} Materials

Aluminum oxide $\left(\mathrm{Al}_{2} \mathrm{O}_{3}\right)$, Aluminum hydroxide $\left(\mathrm{Al}(\mathrm{OH})_{3}\right.$, aluminum (99.999\% pure), lithium (99.99\% pure), anhydrous etha- nol (EtOH), and ovalbumin (OVA) were purchased from SigmaAldrich and used as received.

\section{Fabrication of $\gamma-A / 203 \mathrm{NWs}$}

According to the previous study of transformation from bulk alloys to oxide nanowires [23], a bimetallic Al-Li alloy (50 at.\% lithium) was exposed to anhydrous ethanol ( $\geq 99.5 \%)$ to yield soluble $\mathrm{Li}$ alkoxide and white precipitate $\mathrm{Al}$ alkoxide nanowires $\left(\mathrm{Al}(\mathrm{EtO})_{3} \mathrm{NWs}\right)$. After initial delithiation, $\mathrm{Li}$ alkoxides were decanted and then $\mathrm{Al}(\mathrm{EtO})_{3}$ NWs were washed by extra dry alcohol. The produced $\mathrm{Al}(\mathrm{EtO})_{3} \mathrm{NWs}$ were cast on polyethylene, and 
ethanol was evaporated at room temperature under argon protection. The final step of the $\mathrm{Al}(\mathrm{EtO})_{3} \mathrm{NWs}^{\prime}$ transformation into $\mathrm{Al}_{2} \mathrm{O}_{3}$ NWs involved calcination at $1000{ }^{\circ} \mathrm{C}$ in air at atmospheric pressure.

\section{Materials characterization}

Scanning electron microscopy (SEM) images were obtained using an electron microscope ULTRA 55 (Zeiss, France) equipped with a thermal field emission emitter and three different detectors (EsB detector with filter grid, high efficiency In-lens SE detector, and Everhart-Thornley Secondary Electron Detector). Transmission electron microscopy (TEM) images were recorded on a JEOL TEM 4000EX (JEOL, Japan) operating at $300 \mathrm{kV}$. Thermogravimetric analysis (TGA) was conducted on TGA Q50 analyzer (TA instruments, USA) under air atmosphere at a heating rate of $5^{\circ}$ $\mathrm{C} \cdot \mathrm{min}^{-1}$. The powder X-ray diffraction (X'Pert PRO Alpha-1, USA) was performed using $\mathrm{Cu}-\mathrm{K} \alpha$ radiation to identify the crystalline phase of the composite. X-ray photoelectron spectroscopy (XPS) was performed using a PHl 5000 VersaProbe-Scanning ESCA Microprobe (ULVAC-PHI, Japan/ USA) instrument at a base pressure below $5 \times 10^{-9} \mathrm{mbar}$. Core-level spectra were acquired at pass energy of $23.5 \mathrm{eV}$ with a $0.1 \mathrm{eV}$ energy step. All spectra were recorded with $90^{\circ}$ between X-ray source and analyzer and with the use of low-energy electrons and low-energy argon ions for charge neutralization. After subtraction of the linear background, the core-level spectra were decomposed into their components with the mixed Gaussian-Lorentzian (30:70) shape lines using the CasaXPS software. Quantification calculations were conducted using sensitivity factors supplied by PHI. Fourier transform infrared (FTIR) spectra were recorded using a ThermoScientific FTIR instrument (Nicolet 8700) at a resolution of $4 \mathrm{~cm}^{-1}$. Dried sample $(1 \mathrm{mg})$ was mixed with $\mathrm{KBr}$ powder $(100 \mathrm{mg})$ in an agate mortar. The mixture was pressed into a pellet under 10-ton load for 2-4 min, and the spectrum was recorded immediately. Sixteen accumulative scans were collected. The signal from a pure $\mathrm{KBr}$ pellet was subtracted as the background. Zeta-potential measurements were performed using a Zeta-sizer Nano-ZS (Malvern Instruments Inc. Worcestershire, UK) in clear disposable zeta cell. Samples were diluted to $10 \mu \mathrm{g} \mathrm{mL}^{-1}$ for $\mathrm{Al}_{2} \mathrm{O}_{3}$ MPs, $\gamma-\mathrm{Al}_{2} \mathrm{O}_{3} \mathrm{NWs}$, and $0.2 \%$ for alum in Milli-Q water and were run at $25^{\circ} \mathrm{C}$ in quintuplicate with automatic parameter selection ( $>12$ runs).

\section{Cell viability and internalization}

The HeLa cell line derived from cervical carcinoma [ATCC ${ }^{\circledR}$ CCL$2^{\mathrm{TM}}$, ECACC, Sigma-Aldrich, Saint-Quentin Fallavier, France] and the U-87 MG cell line derived from human brain (glioblastoma astrocytoma) [ATCC $^{\circledR}$ HTB-14 $^{\mathrm{TM}}$, Sigma-Aldrich, Saint-Quentin Fallavier, France] were cultured and maintained in Dulbecco's Modified Eagle's medium (DMEM, Gibco ${ }^{\circledR}$ ) supplemented with $10 \%$ fetal bovine serum (FBS, Gibco ${ }^{\circledR}$ ) and $1 \%$ penicillin-streptomycin $\left(\mathrm{Gibco}^{\circledR}\right)$ in a humidified incubator at $37^{\circ} \mathrm{C}$ and $5 \% \mathrm{CO}_{2}$.

Cells were seeded at a density of $10^{4}$ cells/well in a 96-well plate and grown for $24 \mathrm{~h}$ before assay. The culture medium was replaced with a fresh medium that contains $\gamma-\mathrm{Al}_{2} \mathrm{O}_{3} \mathrm{NWs}$ and alum hydroxide $2 \%$ at different concentrations. After $24 \mathrm{~h}$, the old medium was aspirated, washed with PBS and replaced with a fresh medium. The cell viability was evaluated using Uptiblue (Interchim) method. Briefly, $10 \mu \mathrm{L}$ of the Uptiblue solution was added to each well containing $100 \mu \mathrm{L}$ of DMEM with $10 \%$ FBS and the plate was incubated for $4 \mathrm{~h}$ in the humidified incubator. The fluorescence of each well (excitation $540 \mathrm{~nm} / \mathrm{emission}$ $590 \mathrm{~nm}$ ) was measured using a microplate reader (PHERAstar FS, BMG LABTECH GmbH, Germany). Each condition was replicated five times and the mean absorbance value of non-exposed cells was taken as $100 \%$ cellular viability.

\section{Cytotoxicity studies on macrophages}

The human monocytic THP-1 cells were cultured and maintained in culture in Roswell Park Memorial Institute medium (RPMI 1640, Invitrogen) supplemented with 10\% fetal bovine serum $\left(\mathrm{FBS}, \mathrm{Gibco}^{\circledR}\right), 1 \%$ penicillin-streptomycin $\left(\mathrm{Gibco}^{\circledR}\right)$ and $50 \mu \mathrm{M} \beta$-mercaptoethanol in a humidified incubator at $37^{\circ} \mathrm{C}$ and $5 \% \mathrm{CO}_{2}$. THP-1 monocytes were differentiated into macrophages by a 5-day incubation with $20 \mathrm{nM}$ phorbol 12-myristate 13-acetate (PMA, Sigma) and seeded at a density of $1.5 \times 10^{4}$ cells/well in a 96-well plate. The culture medium was replaced with a fresh medium without $\beta$-mercaptoethanol that contains the compounds from 0 to $400 \mu \mathrm{g} \mathrm{mL}^{-1}$. After $24 \mathrm{~h}$, the cell viability was evaluated using Calcein-AM and PI co-staining. The cells were stained without any washing by addition of $10 \mu \mathrm{L}$ of Calcein-AM/PI mix solution $(45 \mu \mathrm{M} / 30 \mu \mathrm{M})$ in each well and incubated at $37^{\circ} \mathrm{C}$ for $30 \mathrm{~min}$. Subsequently, the stained cells were observed with $4 \times$ objective (GFP and Texas Red filter cubes) using a Cytation ${ }^{\mathrm{TM}} 5$ Cell Imaging Multi-Mode Reader (BioTek Instruments SAS, France).

\section{Animals}

Six-week-old male Balb/c mice were used. The mice were housed in cages covered with air filters in a temperature-controlled room with a 12-h light and 12-h dark schedule and kept on a standard diet with drinking water available ad libitum. Studies involving animals, including housing and care, method of euthanasia, and experimental protocols, were approved by the Ethics committee of Danylo Halytsky Lviv National Medical University, protocol 20180226/2 \& 20130624/6; all experiments were designed to comply with principles of the 3Rs (Replacement, Reduction and Refinement). Totally, 34 mice were analyzed: 12 mice immunized with alum + OVA, 13 mice immunized with $\gamma-\mathrm{Al}_{2} \mathrm{O}_{3} \mathrm{NWs}$ + OVA, 4 mice immunized in $\mathrm{Al}_{2} \mathrm{O}_{3} \mathrm{MPs}+\mathrm{OVA}, 5$ mice immunized with OVA alone; immunization was done in 3 independent experiments.

\section{Mice immunization model}

For correct comparison, $\mathrm{Al}_{2} \mathrm{O}_{3}, \mathrm{Al}_{2} \mathrm{O}_{3} \mathrm{NW}$, and $\mathrm{Al}(\mathrm{OH})_{3}$ were used as pure compounds and prepared as dispersions just before immunization after pre-heating to $150{ }^{\circ} \mathrm{C}$ for $2 \mathrm{~h}$ to eliminate LPS. The dispersions of 'alum $+\mathrm{OVA}^{\prime}, \mathrm{Al}_{2} \mathrm{O}_{3} \mathrm{MPs}+\mathrm{OVA}^{\prime}$, and ' $\gamma-\mathrm{Al}_{2} \mathrm{O}_{3} \mathrm{NWs}+\mathrm{OVA}^{\prime}$ were prepared by mixing OVA and an adjuvant $\left(\mathrm{Al}_{2} \mathrm{O}_{3}, \gamma-\mathrm{Al}_{2} \mathrm{O}_{3} \mathrm{NWs}\right.$ or alum) in phosphate-buffered saline (PBS) by means of the sonication at $44 \mathrm{kHz}$ for a duration of 10 min at $25^{\circ} \mathrm{C}$ until a homogenous clear dispersion is achieved. Suspensions were prepared immediately before the injection. The $50 \mu \mathrm{L}$ of 'adjuvant $(20 \mathrm{mg} \mathrm{mL}-1)+50 \mu \mathrm{L}$ OVA $(1 \mathrm{mg} \mathrm{mL}-1)$ ' 
in PBS were injected intraperitoneally (PI) in mice at day 1 and day 15 of the experiment. The DTH test was performed 28 days after the 1st immunization by injection of $50 \mu \mathrm{L}$ of OVA in PBS $\left(100 \mu \mathrm{g} \mathrm{mL}^{-1}\right)$ into the right hind paw. Injection of $50 \mu \mathrm{L}$ of PBS into the left hind paw was used as a control. The thickness of the paw was measured with a caliper (B110T; Kroeplin Laengenmesstechnik) before the injection and 6, 24, 48, 72, and $96 \mathrm{~h}$ after it, as described previously [18]. Blood was collected from mouse tail before experiment started (day 0 ), before second immunization (day 14), and at the end of experiment (day 35). No more that $50 \mu \mathrm{l}$ of blood was collected to prevent damage to the animal. Serum was isolated (usually $20 \mu \mathrm{l}$ per mice) and immediately frozen.

\section{Air pouch model}

Air pouch model [32] was performed by injection of $5 \mathrm{~mL}$ of sterile air subcutaneously into the back of Balb/c mice to form an air pouch. In two days, an additional $2 \mathrm{~mL}$ of sterile air were blown into the pouch. Two days later, $4 \mathrm{mg}$ of $\gamma-\mathrm{Al}_{2} \mathrm{O}_{3} \mathrm{NWs}, 4 \mathrm{mg}$ of alum in PBS, $4 \mathrm{mg}$ of $\mathrm{Al}_{2} \mathrm{O}_{3}$ MPs, or PBS only was injected into the air pouches of each mice. Next day, mice were sacrificed, and the air pouch membranes were analyzed.

\section{ELISA procedure}

For determination of serum anti-OVA IgG and IgM, immunosorbent NUNC MaxiSorp plates were coated with $50 \mu \mathrm{L}$ of a $5 \mu \mathrm{g} / \mathrm{mL}$ solution of chicken egg albumin in $100 \mathrm{mM}$ carbonatebicarbonate buffer ( $\mathrm{pH}$ 9.6). Plates were incubated overnight at $4{ }^{\circ} \mathrm{C}$ and washed three times with phosphate-buffered saline supplemented with $0.05 \%$ Tween (PBS-T). The plates were blocked with $100 \mu \mathrm{L}$ of $4 \% \mathrm{BSA}$ in PBS-T for $2 \mathrm{~h}$ at $37^{\circ} \mathrm{C}$. To follow the dynamics of $\mathrm{Ab}$ production all serum samples were diluted 1:2000 in washing buffer. Detection was done with goat antimouse IgG(H+L)-HRP (Jackson ImmunoResearch, 115-035-003) for IgG or goat anti-mouse IgM-HRP (Jackson ImmunoResearch, 115-035-020) for IgM, diluted in washing buffer (1:10000). For determination of IgG antibody titers, samples collected at day 35 , after second immunization, were diluted 1:1000, 1:2000, $1: 4000,1: 8000,1: 16000,1: 32000,1: 64000$, and 1:128000. $50 \mu \mathrm{L}$ of prepared solution was added to the well and incubated at $37^{\circ} \mathrm{C}$ for $1 \mathrm{~h}$, after that the plates were washed again. Detection was done using goat anti-mouse $\operatorname{IgG}(\mathrm{H}+\mathrm{L})-\mathrm{HRP}$ (Jackson ImmunoResearch, 115-035-003), which were diluted in washing buffer (1:10000), added to the plates $(50 \mu \mathrm{L}$ per well) and incubated at room temperature for $1 \mathrm{~h}$. After the corresponding washings, the assay was developed with TMB (3,3',5,5'-tetrame thybezidine) containing $\mathrm{H}_{2} \mathrm{O}_{2}$ as a substrate $(50 \mu \mathrm{L}$ per well). The reaction was stopped with $50 \mu \mathrm{l}$ of $1 \mathrm{~N}$ sulfuric acid and absorbance was read at 450 and $620 \mathrm{~nm}$ reference wavelength at Perkin-Elmer HST 7000 BioAssay reader. To account for differences between plates, values were corrected using a standard serum applied on each plate.

\section{Analysis of DNA externalization}

Human granulocytes were isolated from heparinized venous blood of normal healthy donors by Lymphoflot (Bio-Rad) density gradient centrifugation, as described [35]. The granulocyte-rich layer on top of RBCs was taken and subjected to hypotonic lysis of RBCs. Isolated granulocytes were cultured in 96-well culture plates at $5 \times 10^{6}$ cells per milliliter with special inducers of NETosis and with the fluorescent nucleic acid dye Sytox green (Life Technologies). The fluorescence was measured in kinetics for $3 \mathrm{~h}$ using BioAssay Reader HTS7000 (Perkin Elmer), excitation 480/15 nm, emission 535/20 nm.

\section{Acknowledgments}

Sila Nanotechnologies, Ine; the Centre National de la Recherehe Seientifique (CNRS), the University Lille 1, the Hauts-de-France region, the EPLR "Photonies for Society", the Marie Sllodowska-Cunie action (H2020-MSCA-RISL-2015, PANG60836), Volkwagen-Stiftung grant \#no361, and Ministy of Healtheare of Ukraine are acknowledged for financial support. Servier Medical Art is acknowledged as a source of some illustrative materials. We thank S. Peshkova for technical assistance.

\section{Author contributions}

RoBi and SS conceived the idea; RoBi, SP, and TD performed immunization, animal experiments, neutrophil isolation, and ex vivo experiments; RaBo, $\mathrm{AB}, \mathrm{FW}$, and $\mathrm{SZ}$ performed physical characterization; $\mathrm{AB}$ performed cell culture testing; KT and FW synthesized NWs; RB, SS, GU, and KT wrote the manuscript.

\section{Data availability}

The raw/processed data required to reproduce these findings cannot be shared at this time due to technical or time limitations. Q5 563

\section{Appendix A. Supplementary data}

Supplementary data to this article can be found online at https://doi.org/10.1016/j.mattod.2018.10.034.

\section{References}

[1] S.G. Reed et al., Nat. Med. 19 (2013) 1597.

[2] S.R. Bonam et al., Trends Pharmacol. Sci. 38 (9) (2017) 771.

[3] D.J. Marciani, Drug Discovery Today 8 (20) (2003) 934.

[4] A.V. Vinogradov, V.V. Vinogradov, RSC Adv. 4 (2014) 45903.

[5] M. Digne et al., J. Phys. Chem. B 106 (2002) 5155

[6] N.W. Baylor et al., Vaccine 20 (2002) S18.

[7] E.B. Lindblad, Immunol. Cell. Biol. 82 (2004) 497.

[8] B. Sun, T. Xia, J. Mater. Chem. B 4 (2016) 5496.

[9] Z. Maquieria et al., Anal. Chem. 84 (2012) 9340.

[10] S.L. Hem, H. HogenEsch, Expert. Rev. Vaccines 6 (2007) 685.

[11] H. HogenEsch, Vaccine 20 (2002) S34.

[12] C.J. Clements, E. Griffiths, Vaccine 20 (2002) S24.

[13] X.R. Li et al., J. Control Release 173 (2014) 148.

[14] B. Sun et al., ACS Nano 7 (2013) 10834.

[15] B. Sun et al., ACS Appl. Mater. Interfaces 9 (26) (2017) 21697.

[16] X. Li et al., ACS Appl. Mater. Interfaces 9 (27) (2017) 22893.

[17] R. Bilyy et al., Front. Immunol. 7 (2016) 424.

[18] L.E. Muñoz et al., Proc. Natl. Acad. Sci. 113 (40) (2016) E5856.

[19] J. Desai et al., Sci. Rep. 7 (1) (2017) 15003

[20] A.A. Manfredi et al., Front. Immunol. 9 (2018) 288.

[21] V. Papayannopoulos, A. Zychlinsky, Trends Immunol. 30 (11) (2009) 513.

[22] J. Stephen et al., npj Vaccines 2 (1) (2017) 1.

[23] D. Lei et al., Science 355 (6322) (2017) 267.

[24] F. Wang et al., J. Am. Chem. Soc. (2018).

[25] A. Chhana et al., BMC Musculoskelet. Disord. 16 (2015) 296.

[26] G. Schett et al., RMD Open 1 (Suppl. 1) (2015) e000046.

[27] C. Schorn et al., J. Biol. Chem. 286 (1) (2011) 35.

[28] Kong et al., Dent. Mater. 25 (2009) 1371.

\section{4}

6

67


[29] I.C. Allen, Delayed-type hypersensitivity models in mice, in: I.C. Allen (Ed.), Mouse Models of Innate Immunity: Methods and Protocols, Humana Press, Totowa, NJ, 2013, p. 101.

[30] V. Brinkmann et al., Science 303 (5663) (2004) 1532.

[31] C. Schauer et al., Nat. Med. 20 (2014) 511.
[32] Y.M. Sin et al., Ann. Rheum. Dis. 45 (10) (1986) 873.

[33] D.A. Rowley et al., J. Exp. Med. 110 (5) (1959) 751.

[34] N. Goto, K. Akama, Microbiol. Immunol. 26 (12) (1982) 1121.

[35] A. Tomin et al., Clin. Exp. Immunol. 179 (1) (2014) 17. 